\title{
KENNEDY AND SOEKARNO IN POPULAR MOVIES: A TRANSNATIONAL PERSPECTIVE
}

\author{
Mala Hernawati \\ hernawati.mala@gmail.com
}

\begin{abstract}
A leader is someone who is perceived to represent a community. In nations that apply democracy, where people can choose their president through general election, the chosen leader is certainly someone who can meet the majority's taste and criteria. President Kennedy from the United States and President Sukarno from Indonesia are two examples of the popular leaders that have been adored by their people through generations. This research examines leadership representation of Kennedy and Sukarno in movies, how their characters are built on screen, and the significance of their appearance in movies. This research employs Representation Theory from Stuart Hall combined with Transnational Theory of New American Studies. This research is able to explain the connection between popular fiction and the social and political phenomena in both countries, the US and Indonesia, in the time before the general election. Besides, this research finds shared values and ideology in Kennedy's and Sukarno's leadership represented in movies.
\end{abstract}

Keywords: leadership, movies, representation, ideology, transnational

\section{INTRODUCTION}

This research is inspired by the social and political phenomena before the general election in the US and Indonesia, particularly the presidential election in 2014 in Indonesia and the last two presidential elections in 2008 and 2012 in The United States of America. There were similar things that appeared during the campaigns, the candidates associated themselves with a previous president from the past. In the US, Obama was ideologically identical with President Kennedy. In Indonesia, the effort was obvious. The two candidates, Joko Widodo and Prabowo Subianto, built their images as the next Sukarno. Besides, in the last decade there were many movies that put Kennedy and Sukarno on screens. Those political and cultural phenomena show that there is something in Kennedy and Sukarno which is interesting to explore. Therefore, this paper invites the readers to see American and
Indonesian values and ideology through their popular figures in the movies.

Some American movies which portray the life of Kennedy are chosen for this research. They are JFK, The Thirteen Days, The Kennedys, Killing Kennedy and Parkland. Their ratings on IMdB and Rotten Tomatoes are good and they are the most recent movies about John F. Kennedy. Those movies are considered to be the most representative samples to present the image of John F. Kennedy and to portray the political chaos in the early 1960s. In the Indonesian context, Soekarno, Ketika Bung di Ende, and Ruma Maida will be used to compare. They are chosen because they are the most recent movies presenting Sukarno.

In the United States, even in the world, the name of John F. Kennedy is still quite popular and powerful today. According to a poll sponsored by Gallup, Inc., an American research and global performance management consulting company, John F. 
Kennedy is still considered as the best modern president of the United States. Dugan and Newport reports that nearly threequarters of Americans believe John F. Kennedy will go down in history as an outstanding or above-average president. Another poll conducted by CNN Poll also presents a result that erodes the generation gap among Americans who rank President Kennedy as the top president of the United States for the last fifty years. CCN political editor, Steinhauser, reports that,

There is no real generation gap in Kennedy's approval rating. It stands at $89 \%$ among people under 50 who were not even born when Kennedy was killed, and at 92\% among older Americans, most of whom would have memories of Camelot." CNN releases the result of the poll on the $50^{\text {th }}$ anniversary of Kennedy's assassination. The poll is conducted on November 18-20, 2013 by ORC International with 843 adult Americans questioned by telephone. The survey's overall sampling error is plus or minus 3.5 percentage points (http://politicalticker.blogs.cnn.com/2 013/11/22/cnn-poll-jfk-topspresidential-rankings-for-last-50years/ accessed on April 13, 2014).

For many Americans, John F. Kennedy is not only commemorated for his career in politics. People also recognize him as a superstar. $\mathrm{He}$ was the youngest candidate for president in 1960. Some aspects of his life including his noble family, his beautiful wife Jacqueline Bouvier Kennedy, his popular attraction and some scandals due to his affairs make him into the complete package of United States popular figure. Professor Lewis L. Gould writes for BBCHistory that Kennedy is the "celebrity of the White House." He believes that John F. Kennedy has remained frozen in time as a youthful, vibrant figure (Gould, 2013).
If the United States has John F. Kennedy as the ideal leadership model, Indonesia has Sukarno as the loveable model of Indonesian leadership. This research does not have the intention to compare Kennedy and Sukarno personally in their real life, but to compare their images built on screens. Pramoedya Ananta Toer, a political reporter for the PIA news agency in the Sukarno years (19531956) wrote the biography of Sukarno for Indonesia Monitor, a website containing information about Indonesia. He writes that Sukarno "united his country and set it free. He liberated his people from a sense of inferiority and made them feel proud to be Indonesian" (Toer, n.d.). His opening marks the mighty power of Sukarno. Sukarno is seen as the leader of Indonesian in their struggle for independence.

Officially becoming the president of Indonesia on its independence day, Sukarno led and directed Indonesia through many domestic and international issues, such as Irian colonization by the Dutch, imperialism, communism, the Non-Aligned Movement, regime change, etc. In April 1961, President Sukarno, in respect of an invitation from the United States, visited Washington to have a meeting with the new president of the United States, President John F. Kennedy. Jones (1977) wrote

President Kennedy's impression after having discussions with President Sukarno on some matters, such as Soviet communism, West Irian, and also the negotiation to release Allan Pope, an American pilot who was suspected of getting involved in the Ambon bomb attack in 1958. President Kennedy summed up his private impression of Sukarno as "an inscrutable Asian" (p. 197).

The era of Sukarno came to an end in March 1967. General Suharto became as the successor of President Sukarno. There are some rumors that it was a regime change and 
the United States took part in supporting Suharto overthrowing Sukarno. Furthermore, even though the era of Sukarno ended in 1967 and the New Order under Suharto had its own mechanism to put away all the things related to Sukarno, people from Sukarno's generation are alive to promote his ideology. Toer writes that lately Sukarno's reputation had begun to be reexamined in 1998, the time when the era of Suharto ended. Suharto was ousted by the reformation movement and Sukarno's daughter, Megawati Sukarno Putri, became the first female president of Indonesia. Toer adds, "It was, in a way, Bung Karno's triumphant political comeback" (Toer, n.d.).

The radical demonstration in 1998 by Indonesian youth was the turning point for Indonesia to enter the reformation era that longed to create a healthier, more democratic Indonesia. The New Order which suppressed people's freedom to speak about their aspirations and ideas had lost its power. The fall of Suharto's regime was followed by a great monetary crisis. Indonesia was near collapse. Slowly but surely Indonesia was able to overcome the crisis and even became the most dynamic country in South East Asia. The era of reformation was like an open gate for people's freedom to express and excavate the suppressed feeling during New Order. Besides, it was like the wind of change for the destiny of Indonesia in the future.

One interesting phenomenon one decade after the fall the New Order is that Indonesians have tendencies to recall the past. Some recall the glory of the Suharto era; some also recall the glory Sukarno brought for the country. In 2004, Susilo Bambang Yudhoyono was elected president of Indonesia. In the first term of his presidential era, he was successful in stabilizing the country. He is seen as the one who succeeded to lead Indonesia out of the crisis. He then won again in the next election in 2009. Sadly, his second term was not as bright as his first term. Many politicians and critics state that President Yudhoyono was too cautious in making some important policies. Unfortunately, his reputation suffered when his political party had to deal with many corruption cases.

Having a leader with a very thoughtful and cautious image, supported with the political climate which accommodates freedom of expression, gives many Indonesians the opportunity to express their desire to recall the former leader who had a higher degree of determination. However, people's desire to recall Suharto is not quite as strong as people's desire to recall Sukarno. The evidence can be seen in the Indonesian presidential election of 2014. Both presidential candidates, Joko Widodo and Prabowo Subianto, put some obvious effort towards looking like President Sukarno, both ideologically and physically.

Prabowo Subianto imitated the way President Sukarno dressed himself. He always wore a white shirt with pockets on it, the one that Sukarno often wore daily. On the other hand, Joko Widodo did not wear the same outfit as President Sukarno, but he strengthened his image building in the way he made connections with Indonesians. He mingled with the people and created no boundaries between himself and the people. Having a tight-knit relationship with his people was one of the characteristics of President Sukarno. After all, both candidates brought the ideology of President Sukarno: always stick to Pancasila, the five philosophical principles of Indonesia used to build the country. In delivering speeches, both Prabowo Subianto and Joko Widodo made themselves sound like President Sukarno. They talked a lot about food sovereignty, social welfare and distribution, indigenous 
heritage and so forth. In addition, Joko Widodo was supported by Megawati Soekarno Putri, the daughter of President Sukarno. It strengthened the idea that Joko Widodo was ideologically identical with Sukarno.

What can be seen at this point is both in Indonesia and in the United States, there are some certain times when people tend to recall the figures from the past. Therefore, the release of the movies about President Kennedy and Sukarno need to be analyzed beyond the idea that they are only entertainment. The movies accommodate people's imagination of an ideal leader. Therefore, this paper examines how their images are built in the movies.

\section{THEORETICAL FRAMEWORK}

This research is under the new American Studies theory proposed by John Carlos Rowe. According to Rowe (2010), the new American Studies has different characteristics with the American Studies from the 1930s.

The characteristic of a new American Studies can be generally described. No longer focused exclusively on consensus history and assimilationist ideals, American Studies takes into account the many different and constantly changing communities that constitute the United States... Indeed, another crucial development of the new American Studies is the rediscovery of the polyglot history of the United States...The new American Studies is also attentive to the ways the US has participated in traditional imperialism, both in Manifest Destiny and slavery...the new American Studies should take all of the different nations and communities of the western hemisphere as its object of study... Whether or not we accept the hemispheric scope of the new American Studies, the field should be understood as profoundly comparative and transnational, even when it concentrates exclusively on the internal diversity of the US. (Rowe, 2010, pp. 7-8)

Beside that humble idea and that broader space in its scope, new American Studies calls on its scholars to use innovative and established theories and interdisciplinary methodologies to elucidate the larger cultural meanings and social consequences of their criticism. Reviewing Rowe's new American Studies, Whaley explains that Rowe concentrates on a re-reading of literary text and close readings of popular film, television, media, and social problems with the hope that his work might provoke and challenge colleagues also committed to broadening the scope of American Studies and articulating its relationship with complimentary fields (Whaley, 2014).

Entangling the new trend in new American Studies, this research takes movies as the material objects for this research. In order to examine the relationship between producers and consumers, and to find out the ideology in the movies, the present writer uses theory of representation proposed by Stuart Hall, a Cultural Studies thinker. Hall's representation is considered to be the suitable theory to elucidate this popular culture phenomenon. His idea about representation is greatly influenced by the thought of his forerunners like Saussure, Barthes, and Foucault.

According to Hall (1997), representation is the process by which members of a culture use language (broadly defined as any system which deploys signs, or any signifying system) to produce meaning. Hall's definition carries the important premise that thingsobjects, people, events, in the world-do not have in themselves any fixed, final or true meaning. It is people in society, within human cultures-who make things mean 
something, who signify. Meanings, consequently, will always change, from one culture or period to another. There is no guarantee that every object in one culture will have an equivalent meaning in another. Therefore, one important idea about representation is the acceptance of a degree of cultural relativism between one culture and another.

Hall classifies three different approaches to explain how representation of meaning through language works. He call those the reflective, the intentional, and the constructionist or the constructivist approaches. Among others, the constructionist approach has had the most significant impact on Cultural Studies in recent years. The present writer also considers that this approach is the most sufficient for this research. The constructionist approach recognizes the social character of language,

Things don't mean: we construct meaning, using representational systems - concept and signs. Hence it is called the constructivist or constructionist approach to meaning in language. According to this approach, we must not confuse the material world, where things and people exist, and the symbolic practices and processes through which representation, meaning and language operate. Constructivists do not deny the existence of the material world. However, it is not the material world which conveys meaning: it is the language system or whatever system we are using to represent our concept. It is social actors who use the conceptual systems of their culture and the linguistic and other representational systems to construct meaning, to make the world meaningful and to communicate about that world meaningfully to others. (Hall, 1997, pp. 25)

Hall continues explaining that in the constructionist approach, representation involves making meaning by forging links between three different orders of things: what we might broadly call the world of things, people, events and experiences; the conceptual world - the mental concepts we carry around in our heads; and the signs, arranged into languages, which communicate these concepts.

\section{METHODOLOGY}

This research applies a descriptive qualitative approach. According to Creswell (2009), qualitative method is described as approaches used to gather data systematically, but the data is purely descriptive, and therefore not numerical,

Qualitative research is a form of interpretive inquiry in which researchers make an interpretation of what they see, hear, and understand. Their interpretations cannot be separated from their own backgrounds, history, contexts, and prior understandings. After a research report is issued, the readers make an interpretation as well as the participants, offering yet other interpretations of the study. (p. 212)

Furthermore, Best (1970) describes that at times, descriptive research is concerned with how what is or what exists is related to some preceding events that have influenced or affected a present condition or an event. The process of descriptive research goes beyond the mere gathering and tabulating of data. It involves an element of analysis and 
interpretation of the meaning or significance of what is described.

In collecting the data, this research employs library research. The primary data for this research was acquired from the mental evidence: the movies. To support the main data, much information and data was gained from a close book text reading, and exploration from the articles, journals, and the sources from reliable websites on the Internet. The data was collected and then catalogued based on certain topics of discussion.

\section{DISCUSSION \\ IMAGE FORMULATION IN KENNEDY AND SUKARNO MOVIES}

This section shows how movies construct the images of the two legendary leaders, President Kennedy and President Sukarno. The data and surveys show that youths who did not live during their presidential era know and even adore them. The popularity of those figures might be not only supported by the historical texts or historical lessons in class but also by the roles of popular cultures' products, particularly movies. It can be logical since the selected movies that portray the life of President Kennedy and President Sukarno romanticize their private and political life, so they become so loveable to the audiences,

But what about the historical film which fictionalises history? To begin with, it must be understood and conceded from the viewpoint of accuracy, that all historical films are fictional to a lesser or greater extent. If they were not be, they would bore the audience to death and fail at the box office. Without the play of imagination, fictional characters, invented minor events and emotional responses of historical persons the historical film cannot be made. (Deshpande, 2004)

From that quotation, movies have their own ways to describe history or to create images because they should meet market demands which means providing what people are likely to watch. Even though movies are not the real depiction of someone, they still play important roles in building an image or reputation which accommodates the imagination of the audiences. However, historical movies still need to stick to the grand historical narration. They cannot make the story and the setting out of history. They should be careful in choosing the casts because the audiences have had formulaic images of those popular figures. This research finds four classifications that specify the similarities and contrasts of Kennedy and Sukarno's leadership representation in movies: psychical and personality qualities, faith and religious identities, ideology, family and scandals.

\section{A. PSYCHICAL AND PERSONAL QUALITY}

Almost all people agree that both Kennedy and Sukarno were charismatic presidents. They both have physical and inner beauty that people cannot resist. Therefore, all the casts to play their roles need to meet certain qualities to bring the nuance of the reality on screens. Since they are popular figures and everyone seems to recognize them, all the movie about them need to maintain the reality even though it is in the movies.

Pictures below are the actors who played Kennedy in previous movies. At a glance, they look alike. It proves what has been discussed above that the actors who play Kennedy are chosen for some certain criteria, such as, possessing the qualities of John F. Kennedy, at least in their physical appearance 
so they can generally represent a fine image of Kennedy.

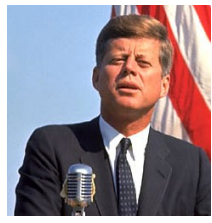

Figure 1.

The real

President

Kennedy

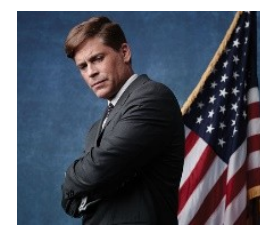

Figure 2. Rob

Lowe as

Kennedy in

Killing

Kennedy (2013)

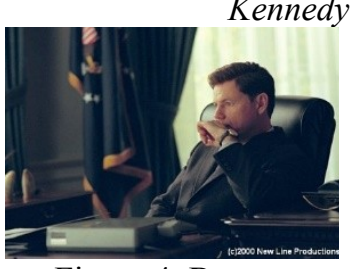

Figure 4. Bruce

Greenwood as

Kennedy in The

Thirteen Days (2000)

In Oliver Stone's JFK (1991) movie, there is no actor to play as Kennedy, but in the beginning of the movie there is a scene which portrays the real gunshots incident in Dallas. In this movie, the audiences are directed to think of the real John F. Kennedy who is known as the celebrity of the White House.

The Thirteen Days (2000) dramatically shows the audiences that the job of being Mr. President is really hard to do. Greenwood as President Kennedy successfully brings the audiences to see his dilemma in dealing with the Cuban Missile crisis in 1962. As the president of the United States, Kennedy does not only work with his logic and strategy but also with his heart in making the decisions to start a war or to go on a diplomatic mission. The movie shows the internal conflict between President Kennedy and his military and defense advisors. President Kennedy insists on preventing the war but almost all his advisors suggest that he should take military action to cope with the Cuban Missile issue. This contrast develops the strong image of President Kennedy as the protagonist together with his brother, Robert
Kennedy and White House aide, Kenny McDonell.

A Harvard historian, May (2001) in his analysis writes that The Thirteen Days is successful in (1) building the image of Kennedy as a very thoughtful president, and (2) making the Cuban Missile crisis as the greatest crisis in the world history,

...the film succeeds in representing the presidency as demanding very high intelligence and cool judgment...Bruce Greenwood's wholly believable performance as John F. Kennedy in Thirteen Days shows a real president - not a Camelot knight but someone who recognizes that he has a very difficult job and that anything he does or says can have huge consequences. (May, 2001)

As it has been discussed in the previous chapter, Blight and Lang's analysis (2013) explains that Kennedy is a 'black swan' - the one who is different with the others. It can be seen clearly in The Thirteen Day. This movie obviously shows the contrast of ideas between Kennedy and his military and defense advisors.

In The Kennedys (2011) series, Greg Kinnear shows the audiences how John F. Kennedy faced many dreadful situations in his life. This movie-series is successful in shaping the image of Kennedy as a victim of situations, at the same time presenting him as a person who had deep consideration and good intention toward what happened around him. It is seen in the movie that from the beginning of his career in politics, Kennedy was a victim of his father's obsession. After the death of Kennedy's oldest brother, Kennedy Sr. lost the son he dreamed to be the future president of the United States. Since he 
saw the potential in his second son, Kennedy Sr. wanted Kennedy to get involved in politics so he could be a presidential candidate. This movie-series shows how Kennedy Sr. demonstrated dirty politics in order to put Kennedy in congress as a senator. However, the movie shows that Kennedy was morally clean and did not take part in unacceptable practices. Running for presidential candidate in 1961 made Kennedy so busy and tired. The movie-series shows how Kennedy's backbone disturbed him from the beginning of the campaign until he earned his job as president. For so many decisions he made, he had to bear the pain he felt in his backbone. This kind of show certainly attracts the sympathy of so many people in realizing that Kennedy was not healthy.

In Killing Kennedy (2013), Rob Lowe acts as Kennedy. In contrast to The Kennedys, Lowe plays Kennedy's role as a stronger and happier character. The beginning of the movie shows the most popular scene in Kennedy movies where John F. Kennedy plays ball with his children and family. It shapes his image, not only as a father for the United States but also as a charming father for his children.

On the other hand, Sukarno is no less magnetic and attractive. Similar to Kennedy's case, the actors are chosen to meet certain criteria of being Sukarno. Indonesians have already had an imagination about Sukarno. Therefore, the movie's makers cannot make the characters of Sukarno out of the characteristics of Sukarno. All the Sukarno actors are set as much as possible to imitate the real Sukarno.

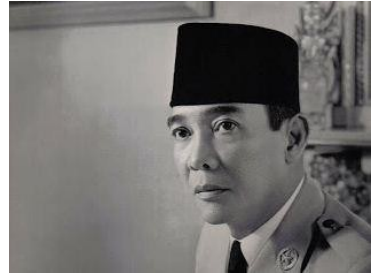

Figure 6. The real Sukarno

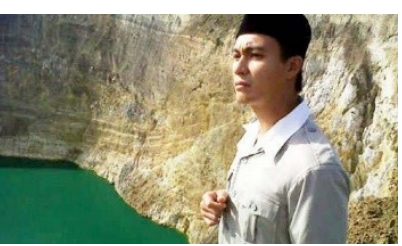

Figure 8. Baim Wong as

Sukarno in Ketika Bung di Ende (2013)

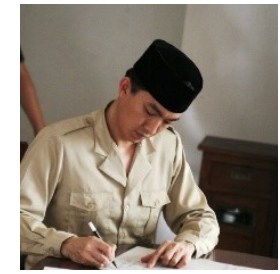

Wibowo as Sukarno in

Ruma Maida (2010)

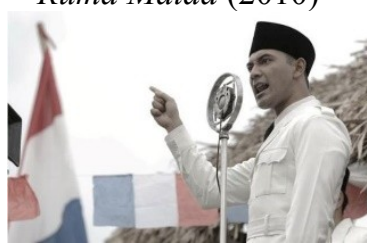

Figure 9. Ario Bayu as

Sukarno in Soekarno

(2013)
Figure 7. Imam

In Soekarno (2013), Ario Bayu plays the role of Sukarno. To get his role as Sukarno, he had to compete with another notable actor in Indonesia, Anjasmara, who had experienced playing Sukarno in several shows. Bayu is capable of presenting Sukarno as a firm, charming, and confident character at the same time. In Soekarno (2013), the audiences can see Sukarno as a person who commits to bringing the Indonesian people to their independence. In his young age, the leadership blood flowed from his heart. He got the knowledge for his speeches from his teacher, Tjokroaminoto. He was also a smart student in his engineering class at Institut Teknologi Bandung (Technical Institute of Bandung). One important thing about Sukarno, he was brave enough to speak about his ideology. He for several times was put in jail because he openly stood against the Dutch colonists. Soekarno (2013) portrays Sukarno's perseverance while he was in exile.

Ketika Bung di Ende (2013) concerns with the life of Sukarno during his exile in Ende, the capital city of East Nusa Tenggara province. In this movie, Baim Wong builds the character of Sukarno as a patient and wise man. Sukarno here is also portrayed as a loyal husband, and a very lovable son and 
father. In Ende, Sukarno lived with his wife, Inggit, his mother in law, and his adopted daughter, Omi. He spent much of his time with them. Therefore, this movie successfully shapes the image of Sukarno as a family man.

In this movie, everyone in Ende seems afraid to get close to Sukarno. They do not want in put themselves in trouble by having contact with him. Therefore, Sukarno in this movie is depressed because there is nothing he can do on the land where almost all the people do not want to have contact with him. With his perseverance, he patiently tries to make connections with the locals. Wong is able to show the modesty of the leader to start every communication with the locals. Finally, Sukarno wins the locals' hearts; people come to his house for routine pengajian (activity to learn and read the holy Quran). Here, Sukarno is presented as a humble and generous person.

In Ruma Maida (2010), Sukarno does not appear much in scenes. Sukarno is portrayed as an art and peace lover. There is a scene in this movie that shows him enjoying the piano music played by Isa Pahing who created the song Pulau Tenggara (South East Island), which becomes the inspiration of Sukarno to form the Non Aligned Movement since Indonesia does not tend to support the West and the East Bloc.

At the end of this movie, Maida, the main character of this movie asks her students to always remember what President Sukarno always said, "Jas Merah...Jangan sekali-kali melupakan sejarah" [Do not ever forget the history]. Sukarno here is commemorated as a leader who learned a lot from the history of his predecessors and stuck to the norm and tradition of eastern culture.

Overall, from the movies, it can be seen that there is similarity between all of them. Those figures are portrayed as good leaders and family men-men with pure hearts who want to contribute something good to society. In addition, the movies show the scenes of both presidents with the background of their national flags. It builds the strong connection between both figures and their countries. It strengthens the patriotic sense in them.

\section{B. FAITH AND RELIGIOUS ATTRIBUTES}

In the discussion of faith and religious identities, there is an obvious difference between President Kennedy and President Sukarno. In the Kennedy movies, Kennedy does not imply anything in accordance with his religion. People know that Kennedy has religion due to the WASP myth in the US. Kennedy was a Catholic and the majority of the United States people are Protestant.

In The Kennedys (2011), the only religious practice shown in the movie is portrayed by Kennedy's mother. She is a very faithful Catholic, during the hard times she shows her faith toward Jesus Christ that he is the only one who can help her sons to overcome many obstacles in their jobs. Kennedy's father is the opposite, and does not believe in God. He becomes aware of God right after the death of President Kennedy. President Kennedy himself and his family never show their religious identity. Based on that fact and referring to the explanation that movies represent what people like, it can be seen that there is no need for movie producers to show Kennedy's religious practices or attributes since it is different with the majority.

On the other hand, the image of Sukarno in the movies is always associated with his religion, Islam. The image of Sukarno cannot be separated from his peci, a Moslem head- 
cover, which he always wears in every occasion. The appearance of Sukarno's character is always associated with Moslem attributes. It becomes an important thing to show to the audiences because the producers know the nature of Indonesian people. If the United States has WASP myth to be a leader, which stands for White Anglo Saxon Protestant, Indonesians also have their own myth of leadership. The leader is supposed to be Javanese and Moslem. However, Indonesians somehow are sensitive with the religion issue. The majority of Indonesians embrace Islam as their religion and throughout history Indonesia has never had a non-Moslem president. Knowing the nature of the market and the Islamization in Indonesia, the producers always consider it as a significant point to show the religious attributes in Sukarno movies.

Furthermore, both in Soekarno (2013) and Ketika Bung di Ende (2013), there are scenes that show Sukarno doing prayers. In Soekarno (2013), Sukarno appears doing shalat, Moslem prayers, before he makes important decisions. In Ketika Bung di Ende (2013), Sukarno also appears doing shalat. There is one scene in Ketika Bung di Ende (2013) that shows Sukarno sitting by the sea. He prays and begs Allah to lend him the power of the sea waves that are never tired of rolling up and are able to break the coral. $\mathrm{He}$ wants Allah to give him that kind of power so he never feels too tired to struggle for Indonesia's independence.

In Soekarno (2013), Sukarno works as a teacher in one Muhammadiyah school in Lampung. Muhammadiyah is a big Moslem organization in Indonesia. It is an old Moslem organization noted as the Islam reformist organization whose main activities are in religion and education. Muhammadiyah is also identical with Islamic modern thinkers.
At this point, it can be concluded that the way producers decide what to show and what not to show depends on the target market for their products. The image of Sukarno and Kennedy are shaped to meet the market demand and to gain more profit for the producers.

\section{IDEOLOGY: DEMOCRACY}

Even though Sukarno and Kennedy lived on different parts of the globe, in the movies, their ideologies manifested and their ways of thinking are presented almost the same way. Both are humanitarian and libertarian. They struggle for the goodness of mankind, and the most visible one is they both promote democracy.

In The Thirteen Days (2000), in many scenes the audiences see the different arguments between John F. Kennedy and his military and defense advisors and also the congress.

President Kennedy: Look, I don't want a god-damn pep talk; you're not the Harvard quarterback anymore. We're on the brink here! They're trying to second-guess me into World War III - well it's not gonna happen!

Kenny O'Donnell: What did you think Congress was gonna do?

President Kennedy: Well, I, you know...

(Donaldson, 2000)

This movie successfully puts John F. Kennedy in a very hard situation dealing with the Cuban Missile crisis. President Kennedy does not want to go to war with Cuba or the Soviet Union, but his military and defense advisors push him to send a military force to Cuba as soon as possible. Some of his advisors including Le May, Bundy, McNamara, etc. scold him in the back as a weak person who cannot handle the nation 
when it is on pins and needles. Fortunately, John F. Kennedy has loyal advisors who stand by his side, such as, his brother Robert Kennedy and Kenny O’Donnel,

McGeorge Bundy: These people are right, and the Kennedys are wrong. We need you to talk to them - they'll listen to you. Jack and Bobby are good men but it takes a certain amount of...

Kenny O'Donnell: You mean the president of the United States-?

McGeorge Bundy: They are good men...

Kenny O'Donnell: -and the attorney general?

McGeorge Bundy: Kenny, they're good men but it takes a certain character - moral toughness - to stand up to the Soviets.

Kenny O'Donnell: [whispering] You listen to me. You're in the White House right now because of the Kennedys. Now, they may be wrong; they make mistakes, but they are not weak. The weak ones are these people who can't seem to speak their own minds.

(Donaldson, 2000)

The movie also successfully shows the basic ideology of Kennedy, which was making peace all around the world. In the movie, he does not like war and really takes a deep consideration in deciding whether it is necessary or not to use military force.

President Kennedy: "What kind of peace do we seek? I am talking about genuine peace, the kind of peace that makes life on earth worth living. Not merely peace in our time but peace for all time. Our problems are manmade - therefore, they can be solved by man. For, in the final analysis, our most basic common link is that we all inhabit this small planet. We all breathe the same air. We all cherish our children's future. And we are all mortal."

(Donaldson, 2000)

Finally, at the end of the movie, the closing remark from Kennedy emphasizes his ideology.

President Kennedy: You know, it's been a long two weeks and, uh - or whatever - but I'd like to thank you all; I think you all did a great job, and I just think - I don't think we should be gloating too much, 'cause it was just as much a victory for them as it was for us... Enjoy your morning.

(Donaldson, 2000)

For those quotations from the movie the audiences see that victory according to Kennedy is not winning the war but preventing the war. The audiences also see the humility that President Kennedy has, the victory of preventing war is the victory of everyone; the real victory of mankind.

In Soekarno (2013), Sukarno also presents the same spirit. Several days before the Independence Day, the Indonesian youth under Sukarni's influence were not patient waiting for independence. They forced Sukarno to declare the independence of Indonesia as soon as possible. They accused Sukarno as a traitor who stood on Nippon's side and did not struggle for the sake of Indonesia's independence. Sukarno insisted on his principle not to declare independence in a rush because he was aware that careless action might cause great suffering for Indonesians. He did not want to see his people to be the victims of independence (in making several deals with both Dutch colonist and Nippon, Sukarno always required that they would not hurt 
Indonesians). He made the safety of his people as his top priority and tried to maintain peace.

Dealing with democracy, Soekarno (2013) successfully portrays the way Sukarno led the meeting with the Indonesian important figures to set the ideological and philosophical principles of the country. On June 1, 1945, Sukarno came in front of the committee and presented the idea that he had in mind since he was in exile. He drew the following five principles: (1) Kebangsaan Indonesia [Indonesian Nationality]; Internasionalisme [Internationalism]; Musyawarah Mufakat [Deliberative Consensus]; (4) Kesejahteraan Sosial [Social Welfare]; Ketuhanan yang Berkebudayaan [Cultural Religiosity]. Those principles drawn by Sukarno greatly influenced the philosophical foundation of Indonesia which is now known as Pancasila. After having some rearrangements by the other members of the Investigating Committee for the Preparation of Independence (Badan Penyelidik Usaha Persiapan Kemerdekaan Indonesia, BPUPKI), Sukarno's idea was transformed to be the following: (1) Ketuhanan Yang Maha Esa [Belief in the one supreme God]; (2) Kemanusiaan Yang Adil dan Beradab [Justicial and Civilized Humanity]; (3) Persatuan Indonesia [The unity of Indonesia]; (4) Kerakyatan Yang Dipimpin oleh Hikmat Kebijaksanaan, Dalam Permusyawaratan dan Perwakilan [Democracy guided by inner wisdom in the unanimity arising out of deliberations among the representatives]; (5) Keadilan Sosial Bagi Seluruh Rakyat Indonesia [Social justice for all Indonesians]. From those principles, the audiences know the basic ideologies of Sukarno, which were humanity, justice, and democracy.

However, even though there was a parallel between Kennedy and Sukarno's spirit, but there is absolute difference in the way they practiced democracy, which shows the culture of each country. There are scenes when Kennedy has meetings with the other White House officers. The nuance of the meeting is casual. There is no certain sitting arrangement or anything that differentiates president from the others. The people involved in the meetings are free to stand or to sit down on their chairs. They are also free to position themselves in their comfortable styles. It represents the nature of Americans. These movies show that equality and democracy are embedded in the blood of Americans. People come to the meeting with something in their mind and they are free to speak it. There is no border that distinguishes president and his staff. During the meetings, even when someone does not agree with the president, they literally say that.

On the other hand, Indonesians culture is different with American culture. There are also scenes that show Sukarno leads the meetings. Sukarno comes in front of the others to present his idea. From the way he takes position and distance from the others, it represents Indonesian culture. There is an invisible distance between the leader and his followers. The position of the leader is in the front of the others; he or she is higher and more powerful than others. It is also related to the social stratification in Indonesian society. Even though Sukarno promotes the spirit of equality, democracy, and freedom, it does not mean that there is no distance between him and his people. In some scenes, Sukarno sits on a chair, and sometimes stands, when he talks to the locals in Ende who sit on the floor. Those scenes depict the social hierarchy that differentiates Sukarno with the others.

\section{FAMILY AND SCANDALS}


Nobody knows the truth, but the discussions on Kennedy and Sukarno are always related to their scandals with many women. Therefore, in the movies that part is never absent. Mr. President's romance and desire seem to be a commercial issue to expose. Many scenes in The Kennedys (2013) show Kennedy's affairs with some women such as his secretary, White House entertainers, and the famous actress Marilyn Monroe. In Soekarno (2013) there are some scenes that imply Sukarno has affairs with some girls. Even though Kennedy and Sukarno are surrounded by scandals, there is a visible difference between them that may cause a significant justification on their image.

In the movies, Kennedy plays with some women but he keeps it a secret-a public secret-that everybody knows even his own wife. Kennedy for several times is warned by Jackie Kennedy not to humiliate her in front of Americans. Each time Kennedy is caught red handed with a woman, he has a guilty feeling but he cannot help it. He tells his brother, Robert Kennedy, there must be a part of a child who wants to play in every man. He only wants to play and he realizes that he has a beautiful lady beside him. He tries to make sense that his affair has no harm for his marriage. He only married Jacqueline Kennedy and kept her as his only wife until he died.

On the other hand, Sukarno has several wives and mistresses. It may relate to the culture and religion since in Islam a man can have more than one wife. In Soekarno (2013), Sukarno left Inggit, his second wife, to marry his adopted daughter's friend, Fatmawati.

Below are the pictures that show how movies depict their scandals. The Indonesian movies do not show the obvious physical contact between Sukarno and his mistresses. On the opposite, American movies show the scandals more obviously than the Indonesian movies.

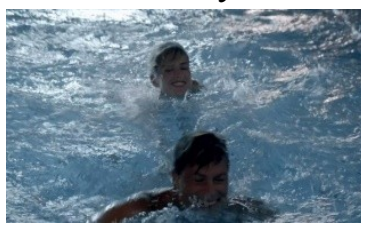

Figure 10. The

Kennedys (2013)

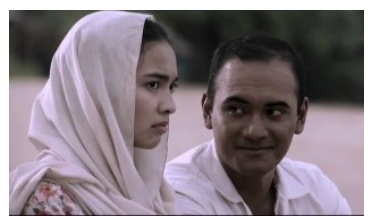

Figure 12. Soekarno (2013)

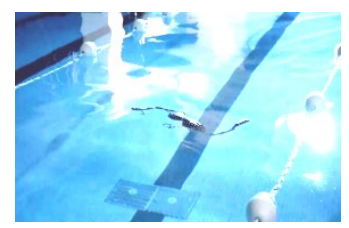

Figure 11. The Kennedys (2013)

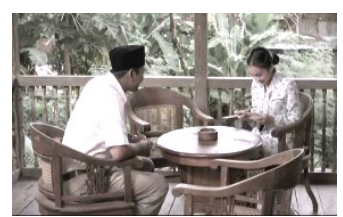

Figure 13.

Soekarno (2013)
Figure 10 and 11 show how Kennedy plays in the swimming pool with some naked girls. The next scene only shows a floating bra in the pool, the audiences are left to think about what it means. The next two pictures show how Sukarno flirts with Fatmawati in the movie Soekarno (2013). They do not engage in physical contact but only tease each other with their eyes and smiles.

Moreover, the movies successfully bring the bias in exposing the affairs of the presidents. They are put in a situation that makes the audience can understand their position. It is the women who are crazy about them. They do not have to do anything, but the women come to them by their own willingness. Therefore, the audiences cannot put the blame on the two leaders only, but on the women too.

One important point is the significance of marriage for both of the presidents. Each needs to affiliate himself with his wife and children. An ideal president is supposed to have a harmonious family. In the Kennedy movies, The Kennedys, The Thirteen Days, and Killing Kennedy, the scenes showing Kennedy playing with his little children are the magnetic part of his life which strengthens his image as a family man. 


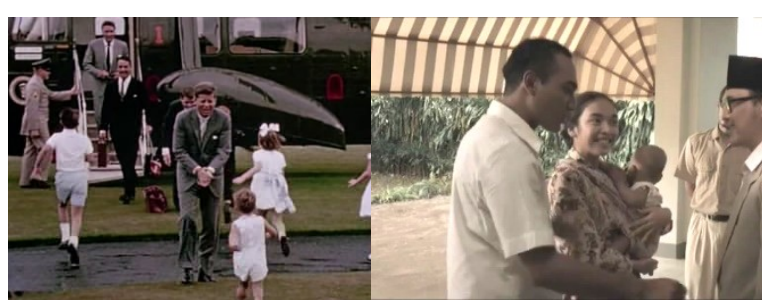

Figure 14. JFK (1991)

Figure 15. Soekarno

(2013)

From the examples above, there is a contrast between the United States and Indonesia on how leadership relates to the value of family. Kennedy with his children playing ball is really something that Americans like to see. On the other hand, in the Indonesian context that kind of display is not considered significant. There is no scene like that in Indonesian movies. If Sukarno plays with his child, the kid is in the hands of the mother. It shows that it was still embedded in Indonesians' point of view that children were supposed to be the mother's business only - a father did not bother himself to take care of his children.

Furthermore there are also many scenes in the movies that show contrasting values between Indonesia and the United States. Below are the pictures that show the contrast of the family value represented by the Kennedy and Sukarno in the movies.

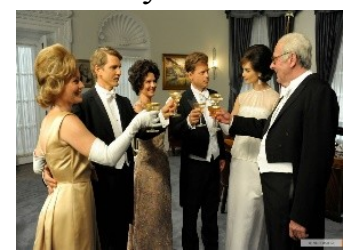

Figure 16.

The Kennedys (2011)

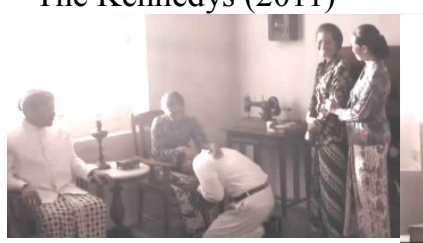

Figure 18.

Soekarno (2013)

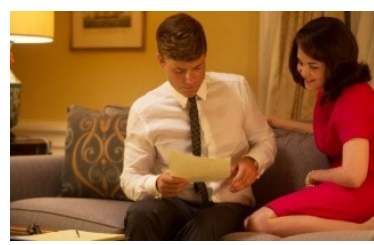

Figure 17.

Killing Kennedy (2013)
Figure 16 shows how American families gather with each member of the family. They gather together and there is no difference between the parents and the children, the old brothers and the young brothers. Figure 17 shows how Kennedy and his wife talk to each other in a casual occasion. As seen in the figure, his wife can do that pose. That thing would not be framed in Sukarno movies because at that time, a wife was seen as a subordinate to her husband, so a wife needed to behave in front of her husband even though it was a casual occasion. The last two figures show the nature of Indonesian people. The parents are higher than the children are. It can be seen in Figure 18 and 19, Sukarno bows his head and kneels in front of his mother. It is important to show to the Indonesian audiences because Indonesians see that as an important criteria for choosing a leader: a good person is the one who loves and obeys his/her parents. It proves that production of movies is really influenced by the social and cultural background of the society.

\section{CONCLUSION}

This research shows that there are some significant points in the appearance of popular figures like John F. Kennedy and Sukarno in the movies. First, the producers know that they are influential figures that people love to see on screens. Second, their images on screens can be interpreted to have several different meanings depending on their time of release. They more than just retell the audiences about the glory or the chaos in the past but at the same time also make the audiences think in romantic way about their past leader. By recalling and romanticizing the figures and the heroic moments in the past, movies produce meanings. More profound than just entertainment, they can be criticism, support or celebration toward the ruling government and also suggestions for the next leader in the near future. One important thing is when people recall or 
memorize something in the past, people also expect things that they may not have in the present.

As a criticism, JFK (1991) can be the example. It was released when the Republicans became the ruling party. In 1991 the United States got involved in the Gulf War. This movie shows a kind of criticism toward the government by recalling the past. This movie wants to say in the past the United States had the figure of Kennedy who was totally different with the ruling leader at that time. Kennedy did not like going to war, but the ruling president at that time did.

Ruma Maida (2009) can be seen as a celebration of the ruling regime. This movie was released in 2009 when Indonesia experienced the era of freedom of speech, act, and expression. This movie is a celebration of the reformation era after the long repressive period of the New Order. The other works that represent the same thing are Killing Kennedy (2013) and Parkland (2013). Those movies are all about Kennedy. Killing Kennedy and Parkland appear to commemorate the $50^{\text {th }}$ anniversary of Kennedy's death.

However, movies can suggest the future leader. Soekarno and Ketika Bung di Ende, both were released in 2013, one year before the Indonesian presidential election in 2014. The release of these movies indeed gave influences toward their audiences in defining what kind of a leader that they wanted to have in the future. This phenomenon also happened in the United States in 2000. The movie The Thirteen Days was released at the end of the Democrat authority, under President Clinton's presidential. In 2001 a presidential election was held in the United States.
At the end, trough representation theory, this research shows that Kennedy and Sukarno in the movies are the representations of the ideologies and values of their societies. Sukarno represents the Indonesian values, such as respecting others, hospitality, religiosity, etc. Sukarno in the movies also shows the dream of Indonesians which is democracy. On the other hand, Kennedy represents the American values and ideologies such as equality and democracy.

\section{REFERENCES}

Bramantyo, H. (Director). (2013). Soekarno [Motion Picture].

Deshpande, A. (2004). Films as Historical Sources or Alternative History. Economic and Political Weekly, Vol. 39, No. 40, 4459.

Donaldson, R. (Director). (2000). The Thirteen Days [Motion Picture].

Eagleton, T. (1991). Ideology. New York: Verso.

Felluga, D. (n.d.). Modules on Lacan: On Desire. Retrieved from Psychology: http://www.purdue.edu/guidetotheory /psychoanalysis/lacandesire.html

Gould, L. L. (2013, November 21). JFK: Celebrity of the White House. Retrieved from BBCHistory: http://www.bbc.co.uk/history/worldw ars/coldwar/kennedy_celebrity_01.sh tml

Hall, S. (1997). Representation: Cultural Representation and Signifying Practices. London: SAGE Publications.

Landesman, P. (Director). (2013). Parkland [Motion Picture].

May, E. (2001). Thirteen Days in 145 Minutes. The American Prospect, Vol. 12, No.1.

McCormick, N. (Director). (2013). Killing Kennedy [Motion Picture]. 
Miller, M. A. (2012, April 3). Indonesian Youth in the Post-1998: Era of Democratization. Retrieved from $\mathrm{Al}$ Arabiya News: http://english.alarabiya.net/views/201 2/04/03/205067.html

Soeriaatmadja, T. (Director). (2009). Ruma Maida [Motion Picture].

Stone, O. (Director). (1991). JFK [Motion Picture].

Surnow, J. (Director). (2011). The Kennedys [Motion Picture].
Toer, P. A. (n.d.). Founding Father and First President. Retrieved from Indonesia Monitor.

Westi, V. (Director). (2013). Ketika Bung Di Ende [Motion Picture].

Whaley, D. E. (2014). What Is This "New" in the New American Studies? Parallel. Retrieved from http://www.49thparallel.bham.ac.uk/ back/issue12/whaley.htm 